\title{
Fire Risk Analysis and Evaluation of Rescue Facilities in the Engineering Laboratory Building
}

\author{
Dani Nugroho Saputro ${ }^{1, *}$ Eni Rahmawati ${ }^{2}$
}

\author{
${ }^{1}$ Faculty of Engineering, Universitas Jenderal Soedirman, Indonesia \\ ${ }^{2}$ Faculty of Health Science, Universitas Jenderal Soedirman, Indonesia \\ *Corresponding author. Email: danisaputro@unsoed.ac.id
}

\begin{abstract}
An important aspect that must be considered in a building design is that apart from being able to use it according to its function and level of strength, it is also necessary to pay attention to the safety aspect against fire hazards. This aspect is very important, considering that there has been an increase in cases of fires in public buildings. This study aims to evaluate the conditions and safety of facilities in buildings against fire hazards. Data collection is done by surveying the existing condition of the building. This study aims to determine and evaluate the reliability and application of fire protection systems in the laboratory building of the Faculty of Engineering, Jenderal Soedirman University. Method data processing using quantitative methods to measure the value of system reliability building safety (NKSKB) against fire hazards based on the manual (pd-T-11-2005-C). The results showed that the NKSKB was 84.29\%. Based on the National Fire Protection Association standards and the Regulation of Minister of Public Works No. 26/PRT/M/2008 concerning Technical Guidelines for Preparation of Master Plans Fire Protection System, shows that the fire protection system and building reliability against fire are in good category (B).
\end{abstract}

Keywords: building reliability, fire protection, safety system

\section{INTRODUCTION}

Safety factors especially fire hazards as consideration important for the people who live in buildings and their environment [1]. In general, trigger fires can be caused by two human factors and factors technical [2]. 62.8\%$75 \%$ of fire problems in Indonesia caused by electricity or there is a short circuit. Other factors that can be causing a fire are arrangement space and lack of infrastructure fire disaster management especially on the problem of fire in the area industry and settlements [3].

Based on statistical data obtained from CTFI (International Association of Fire and Rescue Services) in 2011 to 2015 events fires in the world occur in 43 countries with the highest total cases, in 2011 with a total of $3,375,522$, while for 2015 the total number of fire incidents totaled 2,903,450 cases. in 2015 the death toll was 18,475 people and injured as many as 43,802 people [4]. International Association of Fire and Rescue Services estimates at Indonesia has occurred 20,000 100,000 2015 fire incidents [5].
According to data released by the DKI Jakarta Provincial Fire and Rescue Agency, there were 1,505 fire and rescue cases in DKI Jakarta Province in 2020. Of the total 1,505 fire cases in DKI Jakarta, 938 fire cases were caused by electrical disturbances. Meanwhile, there were 180 cases of fires caused by explosions due to gas leaks, 43 cases of fires caused by candles and cigarette butts [6]. Frequent circumstances, firefighting units come to the location after the fire is getting worse widespread, several factors due to hard to reach location, traffic jam or distance fire unit away from the location fire, therefore a solution is needed to overcome it so that the loss generated can be minimized [7]. Several buildings of public facilities, in this case, office facilities, revealed that there are still weak passive and active fire protection systems that meet the standards [8], [9], [10]. As well as weak awareness of building occupants about the dangers of fire and need to improve regarding the dangers of fire by conducting socialization, adding fire equipment including extinguishers portable, Standard Operating Procedure (SOP) formulation and implementation, and fire organization forming [11], [12]. 
Engineering Laboratory Building Jenderal Soedirman University is one of the buildings that have the potential to the occurrence of fire if you do not have an adequate fire protection system. This laboratory consists of 3 floors for the 1 st floor is the civil engineering laboratory, the $2^{\text {nd }}$ floor is the electrical engineering laboratory, the $3^{\text {rd }}$ floor is the industrial laboratory, and the geological engineering laboratory, in this building there is also a network server center for the entire engineering faculty building. The laboratory has various electronic devices and equipment which if not managed with goodwill becomes trigger happening fire. This study aims to determine the extent of the application of the protection system laboratory fire at the Faculty of Engineering Jenderal Soedirman University based on regulations applied in Indonesia.

\section{METHODS}

The study was conducted at Engineering Laboratory Building Jenderal Soedirman University. This study seeks to an evaluation of fire rescue facilities and fire risk controls at the building structure based on regulations applied in Indonesia. Data were collected using an observational approach consisting of direct observation and measurements on parts of the building. Data were analyzed using the applicable standards, such as NFPA 10, NFPA 13, NFPA 14, NFPA 72, NFPA 101 [13], [14], [15], [16], [17], and the Regulation of Minister of Public Works No. 26/PRT/M/2008 [18]. Technical Requirements for Fire Protection System at Buildings. Method data processing using quantitative methods to measure the value of system reliability building safety (NKSKB) against fire hazards based on the manual (pdT-11-2005-C) composed of active fire protection systems, passive fire protection systems, and means of evacuation.

\section{RESULTS AND DISCUSSION}

This laboratory building is used every day for learning and testing engineering laboratories. Around 200-350 people are active in the engineering faculty laboratory building, including students, lecturers, and staff administrative workers. This laboratory consists of 3 floors for the 1 st floor is the civil engineering laboratory, the 2nd floor is the electrical engineering laboratory, the 3rd floor is the industrial laboratory and geological engineering laboratory, and on the 3rd floor, there is a network server center for all buildings in the engineering faculty. The Fire Tetrahedron explains that a fire can occur because of the meeting of four conditions, involving the existence of fuel, ignition source, oxygen, and chemical reactions. There are many flammable materials in the laboratory building, for example, wood, the paper used by the students, lecturers, and administrative workers, and electronic equipment for testing. The building has a fire risk if not controlled well.

According to the Research and Development Agency for Public Works Regarding Building Fire Safety Inspections, in the form for assessing the reliability of the Building Safety System Components (KSKB) against fire hazards (pd-T-11-2005-C), it states that the condition of each component or part of the building must be assessed or evaluated. The value of the condition of the building fire protection component is divided into three levels, namely: GOOD = "B" ; MEDIUM or SUFFICIENT $=$ "C" $"$ and LESS $=$ "K" (Equivalent value of $\mathrm{B}$ is $100, \mathrm{C}$ is 80 and $\mathrm{K}$ is 60 ). The assessment is based on criteria or restrictions on the condition of the building components.

Reliability assessment of each fire protection system component. The assessment refers to the Regulation of the Public Works Research and Development Agency concerning Building Fire Safety Inspection (pd-T-112005-C) and NFPA 10, NFPA 13, NFPA 14, NFPA 72, NFPA 101. Result of inspection and recording of the real condition of fire protection components used for processing and determining the value of building reliability, as an example can be seen in table 1 .

Table 1. Safety Component Assessment Building

\begin{tabular}{|c|c|c|c|c|c|}
\hline No & Variable & $\begin{array}{c}\text { Rating } \\
\text { result }\end{array}$ & $\begin{array}{c}\text { Rating } \\
\text { Standard }\end{array}$ & $\begin{array}{c}\text { Value } \\
(\%)\end{array}$ & $\begin{array}{c}\text { Conditi } \\
\text { ons } \\
\text { Value }\end{array}$ \\
\hline 1 & 2 & 3 & 4 & 5 & 6 \\
\hline
\end{tabular}

The scoring instructions are Column 1, which contains the scoring number. Column 2, contains safety component variables building. Column 3 , is the result assessment, based on observations direct. Rating presented in the form of letters B, C, or K. Column 4, is the result of column 3 which is presented in the form of numbers. Column 5, in the form of Component percentage value KSKB and Column 6, is the value of the condition of the building's fire protection components. 


\subsection{Completeness of Building Site}

This component regulates how the location and position of the building with the environment surrounding areas related to the danger of fire and how the process of extinguishing. The criteria for assessing the completeness of the site components based on NFPA 14 and based on the Research and Development Agency for Public Works are divided into 4 subsections KSKB and the following are the results of the assessment of the completeness of the site for all buildings of the Faculty of Engineering, Jenderal Soedirman University, which can be seen in table 2 .

Table 2. Results of Assessment of Completeness of Building Site

\begin{tabular}{|c|l|c|c|c|c|}
\hline No & \multicolumn{1}{|c|}{$\begin{array}{c}\text { subsection } \\
\text { KSKB }\end{array}$} & $\begin{array}{c}\text { Asse } \\
\text { ssme } \\
\mathrm{nt}\end{array}$ & $\begin{array}{c}\text { Rating } \\
\text { Standa } \\
\mathrm{rt}\end{array}$ & $\begin{array}{c}\text { Value } \\
(\%)\end{array}$ & $\begin{array}{c}\text { Condit- } \\
\text { on } \\
\text { Value }\end{array}$ \\
\hline I & Site Equipment (max 25 \%) \\
\hline 1 & Water sources & $\mathrm{C}$ & 80 & 27 & 5.4 \\
\hline 2 & Access Road & B & 100 & 25 & 6.25 \\
\hline 3 & $\begin{array}{l}\text { Building } \\
\text { Distance }\end{array}$ & B & 100 & 23 & 5.75 \\
\hline 4 & $\begin{array}{l}\text { Hydrant } \\
\text { (NFPA 14) }\end{array}$ & C & 80 & 25 & 2 \\
\hline
\end{tabular}

The total assessment of the site completeness condition is 22.4 from the maximum value of the site completeness component of 25 . Percentage of conformity $=(22.4 / 25) \times 100 \%=89.6 \%(B)$. Based on table 2, it is obtained that the assessment of the completeness of the site for laboratory buildings is $89.6 \%$, or the condition of the completeness of the site, in general, is in good condition, see fig. 1.
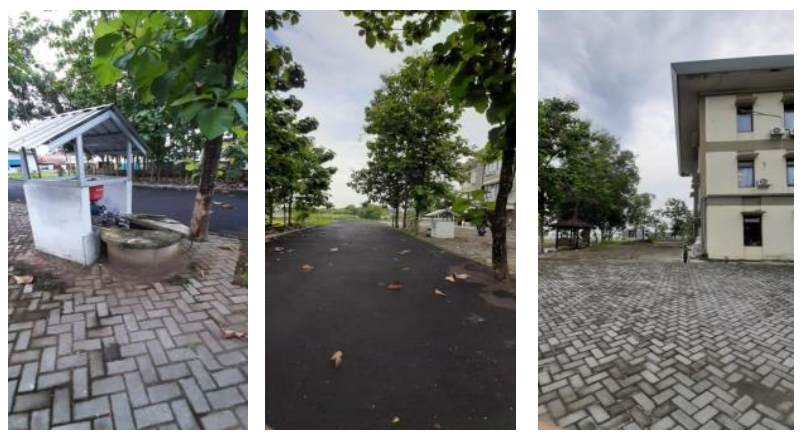

Figure 1 Completeness of Building Site

\subsection{Laboratory Rescue Facilities}

An important component that must be provided in the building is a means of rescue which can be used by building occupants to perform self-rescue safely and insufficient time in case of an emergency such as a fire hazard. Component assessment criteria rescue facility based on Research and Development Agency Public Works is divided into 2 subsections KSKB and the following are the results of the assessment of the Laboratory Building Rescue Facility, Faculty of Engineering, Jenderal Soedirman University which can be seen in table 3 .

Table 3. Results of Assessment of Laboratory Rescue Facilities

\begin{tabular}{|c|l|c|c|c|c|}
\hline No & $\begin{array}{l}\text { subsection } \\
\text { KSKB }\end{array}$ & $\begin{array}{c}\text { Ass } \\
\text { ess } \\
\text { men } \\
\mathrm{t}\end{array}$ & $\begin{array}{c}\text { Ratin } \\
\mathrm{g} \\
\text { Stand } \\
\text { art }\end{array}$ & $\begin{array}{c}\text { Value } \\
(\%)\end{array}$ & $\begin{array}{c}\text { Conditi } \\
\text { ons } \\
\text { Value }\end{array}$ \\
\hline II & Rescue Facilities (max value 25 \%) \\
\hline 1 & $\begin{array}{l}\text { Evacuation } \\
\text { Exit }\end{array}$ & B & 100 & 38 & 9.5 \\
\hline 2 & $\begin{array}{l}\text { Evacuation } \\
\text { exit } \\
\text { constructio } \\
\text { n materials }\end{array}$ & B & 100 & 35 & 8.75 \\
\hline 3 & $\begin{array}{l}\text { Helicopter } \\
\text { Runway }\end{array}$ & K & 50 & 27 & 4.05 \\
\hline \multicolumn{7}{|c|}{ Total } \\
\hline
\end{tabular}

Based on table 3, obtained an assessment of the condition of the means of rescue for Laboratory building as big as $89.2 \%$. This means the condition of the facilities rescue in laboratory buildings is in good condition (B).

\subsection{Active Protection System Facilities}

An active protection system is needed for every building, especially public facilities as an effort to prevent fires where active protection systems such as detectors, building hydrants, fire alarms, fire extinguishers, sprinklers, overflow suppression systems can help limit the spread of fire in the building so that the losses caused by fire can be minimized. Criteria for Active Protection System Facilities components based on NFPA 13, NFPA 10, NFPA 13, NFPA 14, and NFPA 72 and based on Research and Development Agency for Public Works are divided into 13 subsections KSKB and the following are the results of the assessment of the Active Protection System Facilities of the Faculty of Engineering, Jenderal Soedirman University, which can be seen in table 4 . 
Table 4. Results of Assessment of Active Protection System Facilities

\begin{tabular}{|c|c|c|c|c|c|}
\hline No & $\begin{array}{l}\text { subsection } \\
\text { KSKB }\end{array}$ & $\begin{array}{l}\text { Assess } \\
\text { ment }\end{array}$ & $\begin{array}{l}\text { Rating } \\
\text { Standart }\end{array}$ & $\begin{array}{l}\text { Value } \\
(\%)\end{array}$ & $\begin{array}{l}\text { Condit } \\
\text { ion } \\
\text { Value }\end{array}$ \\
\hline III & \multicolumn{5}{|c|}{ Active Protection System (max value $24 \%$ ) } \\
\hline 1 & $\begin{array}{l}\text { Detection } \\
\text { and Alarm } \\
\text { (NFPA 72) }\end{array}$ & K & 50 & 8 & 0.96 \\
\hline 2 & $\begin{array}{l}\text { Siames } \\
\text { Connection }\end{array}$ & K & 50 & 8 & 0.96 \\
\hline 3 & $\begin{array}{l}\text { Fire } \\
\text { extinguisher } \\
\text { (NFPA 10) } \\
\end{array}$ & B & 90 & 8 & 1.73 \\
\hline 4 & $\begin{array}{l}\text { Building } \\
\text { hydrant } \\
\text { (NFPA 14) }\end{array}$ & B & 90 & 8 & 1.73 \\
\hline 5 & $\begin{array}{l}\begin{array}{l}\text { Sprinkler } \\
\text { (NFPA 13) }\end{array} \\
\end{array}$ & K & 50 & 8 & 0.96 \\
\hline 6 & $\begin{array}{l}\text { Overflow } \\
\text { Extinguishin } \\
\text { g System }\end{array}$ & K & 50 & 7 & 0.84 \\
\hline 7 & $\begin{array}{l}\text { Smoke } \\
\text { Control }\end{array}$ & K & 50 & 8 & 0.96 \\
\hline 8 & $\begin{array}{l}\text { Smoke } \\
\text { Detector }\end{array}$ & K & 50 & 8 & 0.96 \\
\hline 9 & Exhaust & $\mathrm{K}$ & 50 & 7 & 0.84 \\
\hline 10 & Fire Lift & K & 50 & 7 & 0.84 \\
\hline 11 & $\begin{array}{l}\text { Emergency } \\
\text { light and } \\
\text { directions } \\
\text { (NFPA 72) }\end{array}$ & $\mathrm{C}$ & 75 & 8 & 1.44 \\
\hline 12 & $\begin{array}{l}\text { Emergency } \\
\text { power }\end{array}$ & B & 90 & 8 & 1.73 \\
\hline 13 & $\begin{array}{l}\text { Operations } \\
\text { Control } \\
\text { Room } \\
\end{array}$ & $\mathrm{C}$ & 78 & 7 & 1.31 \\
\hline & & & & Total & 15.25 \\
\hline
\end{tabular}

Based on table 4, obtained an assessment of the condition of the means of Active Protection System Facilities Laboratory building as big as $63.6 \%$. This means the condition of the facilities rescue in laboratory buildings in less condition (K).

\subsection{Passive Protection System Facilities}

A passive protection system regulates the elements that make up the building structure according to the type of level of resistance to fire, limitation of fire propagation, and available opening protection to limit the spread of fire and smoke due to fire hazards. Criteria for Passive Protection System Facilities components based on NFPA 101 and based on Research and Development Agency for Public Works are divided into 3 subsections KSKB and the following are the results of the assessment of the Passive Protection System Facilities of the Faculty of Engineering, Jenderal Soedirman University, which can be seen in table 5 .
Table 5. Results of Assessment of Passive Protection System Facilities

\begin{tabular}{|c|l|c|c|c|c|}
\hline No & $\begin{array}{l}\text { subsection } \\
\text { KSKB }\end{array}$ & $\begin{array}{c}\text { Asses } \\
\text { sment }\end{array}$ & $\begin{array}{c}\text { Ratin } \\
\mathrm{g} \\
\text { Stand } \\
\text { art }\end{array}$ & $\begin{array}{c}\text { Value } \\
(\%)\end{array}$ & $\begin{array}{c}\text { Cond } \\
\text { ition } \\
\text { Valu } \\
\mathrm{e}\end{array}$ \\
\hline IV & \multicolumn{3}{|c|}{ Passive Protection System (max value 26 \%) } \\
\hline 1 & $\begin{array}{l}\text { Building } \\
\text { Structure Fire } \\
\text { Resistance } \\
\text { (NFPA 101) }\end{array}$ & B & 100 & 36 & 9.36 \\
\hline 2 & $\begin{array}{l}\text { Space } \\
\text { Compartment } \\
\text { ization } \\
\text { (NFPA 101) }\end{array}$ & B & 100 & 32 & 8.32 \\
\hline 3 & $\begin{array}{l}\text { Opening } \\
\text { Protection } \\
\text { (NFPA 101) }\end{array}$ & C & 80 & 32 & 6.66 \\
\hline \multicolumn{7}{|l}{} \\
\hline
\end{tabular}

Based on table 5, obtained an assessment of the condition of the means of Passive Protection System Facilities Laboratory building as big as 93.6\%. This means the condition of the facilities rescue in laboratory buildings is in good condition (B).

\section{CONCLUSION}

Based on the results of the calculation of the value of reliability for each Protection System component, it can be concluded that system assessment results fire protection of the laboratory building faculty of engineering, Completeness of the Site with an assessment result of $22.4 \%$. Rescue Means with an assessment result of $22.3 \%$. Active Protection System with the results of the assessment $15.25 \%$. Passive Protection System with assessment results in $24.34 \%$. Overall system condition assessment fire protection laboratory building faculty of engineering that is by $84.29 \%$. Research and Development Agency Public Works indicates that the condition of the protection system fire in the laboratory building is in good condition (B). With condition what is expected is a protection system can be maintained and function properly when needed fire hazard.

\section{REFERENCES}

[1] P. M. P. Umum, "Peraturan Menteri Pekerjaan Umum Nomor: 26/Prt/M/2008 Tanggal 30 Desember 2008 Tentang Persyaratan Teknis Sistem Proteksi Kebakaran Pada Bangunan Gedung Dan Lingkungan," PERMEN PU No.26/PRT/M/2008, 2008.

[2] S. Ramli, Petunjuk Praktis Manajemen Kebakaran (Fire Management). 2010.

[3] E. Y. Hambaly, M. Setiawati, and A. Majid, "Menghindari Bahaya Kebakaran Melalui Instalasi Listrik yang Benar dan Aman," ETHOS (Jurnal Penelit. dan Pengabdian), 2018, doi: 10.29313/ethos.v6i2.2534. 
[4] N. Brushlinsky, M. Ahrens, S. Sokolove, and P. Wagner, "World Fire Statistics. Bulletin No22," World Fire Stat., 2017.

[5] N. N. Brushlinsky, M. Ahrens, S. V Sokolov, and P. Wagner, "CTIF world fire statistics report," Int. Assoc. fire rescue Serv., 2017.

[6] Dinas Penanggulangan Kebakaran dan Penyelamatan Provinsi DKI Jakarta, Kejadian Kebakaran di DKI Jakarta Tahun 2020. 2021.

[7] "SISTEM DETEKSI KEBAKARAN PADA GEDUNG BERBASIS PROGRAMMABLE LOGIC CONTROLLER (PLC)," J. Karya Ilm. Tek. Elektro, 2017.

[8] R. A. Kowara, "Analisis Sistem Proteksi Kebakaran Sebagai Upaya Pencegahan Dan Penanggulangan Kebakaran," J. Manaj. Kesehat. Yayasan RS.Dr. Soetomo, 2017, doi: 10.29241/jmk.v3i1.90.

[9] R. S. Miranti, "Penerapan Sistem Proteksi Aktif Dan Sarana Penyelamatan Jiwa Sebagai Upaya Pencegahan Kebakaran," Higeia J. Public Heal. Res. Dev., 2018.

[10] S. Arrazy, E. Sunarsih, and A. Rahmiwati, "IMPLEMENTATION OF FIRE SAFETY MANAGEMENT SYSTEM AT DR. SOBIRIN HOSPITAL DISTRICT OF MUSI RAWAS 2013," J. Ilmu Kesehat. Masy., 2014.

[11] I. N. Ayonga, "An Investigation of Fire Emergency Preparedness in Kenyan," an Investig. Fire Emerg. Prep. Kenyan, 2016.

[12] I. Y. Salena, M. Safriani, and Novrizal, "Identifikasi Sistem Proteksi Kebakaran serta Tingkat Keandalan Keselamatan Bangunan Fakultas Kesehatan Masyarakat di Universitas Teuku Umar," J. Pendidik. Tek. Bangunan dan Sipil, 2019.

[13] National Fire Protection Association (NFPA), "NFPA 10 - Standard for Portable Fire Extinguishers," Pat. NFPA 10, 2002.

[14] H. S. Wass and R. P. Fleming, "NFPA 13," in Sprinkler Hydraulics, 2020.

[15] H. Systems, "NFPA 14 Standard for the Installation of Standpipe and Hose Systems 2007 Edition," Secretary, 2007.

[16] NFPA, "NFPA 72: National Fire Alarm and Signaling Systems Code," Natl. Fire Alarm Signal. Code Handb., 2016.

[17] N. F. P. A. NFPA, "NFPA 101: Life Safety Code.," 2015. 2018.

[18] Permen PU No. 22/PRT/M/2018, "Pembangunan Bangunan Gedung Negara," Menteri Pekerj. Umum dan Perumah. Rakyat Republik Indones., 2018. 